\title{
Kinetics of odorant compounds in wine brandies aged in different systems
}

\author{
Ilda Caldeira ${ }^{\mathrm{a}, \mathrm{b}, *}$, Rui Santos ${ }^{\mathrm{a}, \mathrm{c}}$, Jorge M. Ricardo-da-Silva ${ }^{\mathrm{c}}$, Ofélia Anjos ${ }^{\mathrm{d}, \mathrm{e}}$, Helena Mira ${ }^{\mathrm{f}}$, \\ A. Pedro Belchior ${ }^{a}$, Sara Canas ${ }^{a, b}$ \\ a Instituto Nacional de Investigação Agrária e Veterinária, INIAV-Dois Portos, Quinta da Almoínha, 2565-191 Dois Portos, Portugal \\ ${ }^{\mathrm{b}}$ ICAAM - Instituto de Ciências Agrárias e Ambientais Mediterrânicas, Universidade de Évora, Pólo da Mitra, Ap. 94, 7002-554 Évora, Portugal

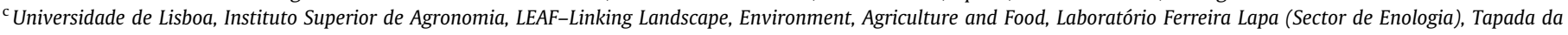 \\ Ajuda, 1349-017 Lisboa, Portugal \\ dinstituto Politécnico de Castelo Branco, Apartado 119, 6001-909 Castelo Branco, Portugal \\ e Centro de Estudos Florestais, Instituto Superior de Agronomia, Universidade de Lisboa, 1349-017 Lisboa, Portugal \\ ${ }^{\mathrm{f}}$ Instituto Politécnico de Santarém, Escola Superior Agrária, Apartado 310, 2001-904 Santarém, Portugal
}

\section{A R T I C L E I N F O}

\section{Article history:}

Received 27 October 2015

Received in revised form 16 May 2016

Accepted 19 May 2016

Available online 24 May 2016

\section{Keywords:}

Wine brandies

Ageing system

Odorant compounds

Kinetics

Oak

Chestnut

\begin{abstract}
A B S T R A C T
The odorants compounds of aged wine brandies comprise compounds deriving from the wood, from the distillate and from the reactions that occur inside the barrel. The aim of this work was to study the kinetics of the odorant compounds of a wine brandy during two years of ageing in two ageing systems.

The odorant compounds in the analysed brandies changed significantly over the time, but with different evolution patterns. The wood related compounds increased over time, with the highest increase in the first months of ageing. The kinetics of cis, trans- $\beta$-methyl- $\gamma$-octalactone, acetovanillone and of seven volatile phenols are established for the first time in brandies. Moreover, a significant effect of the ageing system was found on the kinetics of the wood related compounds. These results pointed out the interest of these compounds as a tool to discriminate different ageing technologies.
\end{abstract}

(c) 2016 Elsevier Ltd. All rights reserved.

\section{Introduction}

Wine brandy is a complex mixture of hundreds of volatile compounds (Nykänen \& Suomalainen, 1983). However, the aroma research has led to the conclusion that only $5 \%$ of the volatiles identified in foods contribute to aroma and these compounds are called key odorants or odour-active compounds. Some studies have screened the key odorants in the aged wine brandies (Caldeira, Bruno de Sousa, Belchior, \& Clímaco, 2008; Jánacová, Sádecká, Kohajdová, \& Spanik, 2008). Some odorant compounds result from the distillate, such as acids, alcohols, esters and terpenes while others originate from the wooden barrel, such as lactones, acids, aldehydes and phenols.

After the distillation, some distillates can remain from several months to many years in wooden barrels. This process, called ageing or maturation considerably modifies the odorant composition

\footnotetext{
* Corresponding author at: Instituto Nacional de Investigação Agrária e Veterinária, INIAV-Dois Portos, Quinta da Almoínha, 2565-191 Dois Portos, Portugal.

E-mail address: ilda.caldeira@iniav.pt (I. Caldeira).
}

of the beverage and its sensory profile. Actually, several factors, such as the kind of wood, the heat treatment of the barrels and the ageing time have a significant influence on sensory and physico-chemical composition of the brandies (Caldeira, Anjos, Portal, Belchior, \& Canas, 2010; Caldeira, Belchior, \& Canas, 2013; Caldeira, Mateus, \& Belchior, 2006; Canas, Leandro, Spranger, \& Belchior, 1999; Canas et al., 2011; Guichard, Fournier, Masson, \& Puech, 1995; Onishi, Guymon, \& Crowell, 1977).

Such modifications are an outcome of several physical and chemical processes that take place in wooden barrels. Nishimura and Matsuyama (1989) classify these processes into seven types for all the matured distilled spirits: direct extraction of wood components; decomposition of macromolecules shaping the wood framework and its elution into the spirit; reactions between the wood compounds and the distillate compounds; reactions involving only the wood compounds; reactions involving only distillate compounds, evaporation of low boiling compounds and formation of stable clusters between ethanol and water.

However, knowledge about these processes has been mainly based on odourless compounds. The understanding about the participation of odorant compounds in the maturation processes is 
still scarce except for vanillin, furanic aldehydes and acetic acid. Vanillin is a phenolic aldehyde correlated with the brandy descriptor vanilla (Caldeira et al., 2008; Jánacová et al., 2008). Its presence in brandies results from an extraction from the wood and from the oxidation of coniferaldehyde (Puech, Leauté, Clot, Nomdedeu, \& Mondiés, 1984). Also the extraction and degradation of the wood lignin by the brandies, a process called hydroalcoholysis leads to the formation of several phenolic aldehydes (Nishimura, Onishi, Masuda, Koga, \& Matsuyama, 1983; Puech, 1981; Puech et al., 1984) namely the vanillin. The vanillin amount in brandies increased during the ageing process (Canas, Caldeira, \& Belchior, 2013; Puech \& Goffinet, 1987; Puech et al., 1984). The furanic aldehydes (furfural, 5-hydroxymethylfurfural and 5-methylfurfural) are correlated with dried fruits attribute in brandies (Caldeira et al., 2008; Jánacová et al., 2008). Their amounts increase over time (Canas et al., 2013; Onishi et al., 1977) and it is more pronounced in the initial phase of ageing. The acetic acid is present in the fresh distillate (Puech et al., 1984). Its content increases during the ageing process (Puech et al., 1984), as a result of acetaldehyde oxidation and of wood extraction (Nishimura et al., 1983; Reazin, Baldwin, Scales, Washington, \& Andreasen, 1976).

As for other odorant compounds, such as volatile phenols, acetovanillone, $\beta$-methyl- $\gamma$-octalactone, esters, acids and alcohols, some studies reported their increase during the ageing process (Cantagrel et al., 1992; Onishi et al., 1977; Otsuka, Zenibayashi, Itooh, \& Totsuka, 1974; Puech et al., 1984) but there is no published data about their kinetics during the ageing time. With regards of some volatile phenols and $\beta$-methyl- $\gamma$-octalactone some information could be collected from the Spillman, Iland and Sefton study (1998) that followed the wood barrel extraction by a hydroalcoholic solution (10\%) for two years.

The physical and chemical processes that occur during brandy ageing were established for the traditional ageing process using wooden barrels. However, more recently some research has been done on alternative ageing systems (Anjos, Carmona, Caldeira, \& Canas, 2013; Caldeira et al., 2010; Caldeira et al., 2013; Canas, Caldeira, \& Belchior, 2009a, 2009b; Canas et al., 2013; Cruz, Canas, \& Belchior, 2012; Schwarz, Carmen Rodríguez, Sánchez, Guillén, \& Barroso, 2014). The use of wood fragments inside the wine brandy showed interesting results concerning the sensory quality of the brandies, however the brandies produced using alternative ageing systems present a quite different composition.

The goals of the present paper are, firstly to describe the changes in odorant compounds that take place during the maturation of a wine brandy in wooden barrels; secondly, to evaluate the patterns of those changes, and thirdly to compare the patterns with those occurred in the same brandy aged in an alternative system, while taking into account the volatile composition of the toasted wood used in each system.

\section{Materials and methods}

\subsection{Experimental design and sampling of wood and brandies}

The experiment was based on a factorial design, where the first factor was the ageing system with two levels (traditional ageing in barrels-B and alternative ageing with staves inside the stainless steel tanks-S) and the second factor was the ageing time with seven levels $(8,15,90,180,365,545$ and 730 days). Two replicates of each essay modality were done.

The four experimental units of this experiment, two wooden barrels $(650 \mathrm{~L})$ and two stainless steel tanks $(3000 \mathrm{~L})$ were filled with the same wine distillate from Lourinhã (Portugal). The wooden barrels were made of oak wood from Limousin (Quercus robur L.) and chestnut wood (Castanea sativa Mill) staves organized alter- nately. A number of staves $(91 \mathrm{~cm}$ length $\times 5 \mathrm{~cm}$ width $\times 1.8 \mathrm{~cm}$ thickness), from the same two types of wood, were also put alternately inside the stainless steels tanks. The number of staves was calculated in order to simulate the surface area to volume ratio of a $650 \mathrm{~L}$ barrel. During the ageing period, macro-oxygenation was carried out monthly in the stainless steel tanks with staves.

The wooden barrels and the staves were made by a Portuguese cooperage (J.M. Gonçalves at Palaçoulo, Portugal). Both were submitted to a medium plus toasting level (90 min at an average temperature of $240{ }^{\circ} \mathrm{C}$ ). The barrels were heated over a fire made of wood offcuts and the staves were heated in an industrial oven.

Samples of wood were taken after the toasting process. Two staves of each wood were randomly drawn and fully processed into chips. The chips from the four staves were mixed in order to reproduce the situation used in the stainless steel tanks and two samples were taken. Regarding the barrels, the wood sampling was performed by gathering the wood chips of each barrel and then the sample is taken. A total of four wood samples were taken after the heating process in order to analyse their volatile composition.

The four experimental units (two wooden barrels and two stainless steel tanks with staves) were filled with the same wine distillate $(77.3 \% \mathrm{v} / \mathrm{v})$, produced by Adega Cooperativa da Lourinhã - ACL (Lourinhã, Portugal) and they were placed in analogous conditions in the ACL cellar. Each experimental unit was sampled over time respectively at $8,15,90,180,365,545$ and 730 days of ageing. All the aged brandy samples and the sample of brandy without ageing, the control sample (C), were analysed.

\subsection{Chemicals}

Dichloromethane and sodium sulphate anhydrous, both analytical grade, were purchased from Merck (Darmstadt, Germany). The dichloromethane was redistilled in a Vigreux column. The GC-FID and GC-MS standards are presented in the Table 1 . Because the $\beta$-methyl- $\gamma$-octalactone standard contained a mixture of the cis and the trans isomers, the proportions of the two isomers were determined before being used for calibration.

Water was purified through a Seralpur Pro $90 \mathrm{CN}$ from SERAL (Water Purification Systems in Ransbach - Baumbach).

\subsection{Wood analysis}

\subsubsection{Wood moisture}

The wood moisture was determined in a moisture analyser (Mettler LJ 16-Switzerland).

\subsubsection{Wood extraction}

Hydroalcoholic wood extracts were obtained according to previous methodology (Caldeira, Pereira, Clímaco, Belchior, \& Bruno de Sousa, 2004) with some modifications. $50 \mathrm{~g}$ of milled wood (Retsch ZM 100, Haan, Germany) was macerated under rotary agitation for $180 \mathrm{~min}$ at $20^{\circ} \mathrm{C}$, with $1000 \mathrm{~mL}$ of an ethanol-water solution at $77.3 \% \mathrm{v} / \mathrm{v}$ adjusted to $\mathrm{pH} 5.45$. The hydroalcoholic wood extracts were filtered through a glass microfiber filter (Whatman $\mathrm{GF} / \mathrm{C}$ ) in a Buchner funnel.

\subsubsection{Quantification of volatile compounds by GC-FID}

$100 \mathrm{ml}$ volume of hydroalcoholic wood extract (diluted to $20 \%$, $\mathrm{v} / \mathrm{v}$ ) was extracted with dichloromethane, dried over sodium sulphate anhydrous and then concentrated to a final volume of 100 $-200 \mu \mathrm{L}$ (Caldeira et al., 2004). The concentrated wood extracts were maintained at $-20^{\circ} \mathrm{C}$ until GC-FID and GC-MS analysis.

The gas chromatographic analysis was carried out in Agilent Technologies 6890 Series chromatograph (Wilmington, DE, USA) equipped with a flame ionization detector (FID) and a fused silica 
Table 1

Odorant standards used: CAS number, supplier and purity.

\begin{tabular}{|c|c|c|c|}
\hline Analyte & $\begin{array}{l}\text { CAS } \\
\text { number }\end{array}$ & Supplier & $\begin{array}{l}\text { Purity } \\
(\%)\end{array}$ \\
\hline 2-Methyl-1-propanol (isobutanol) & 78-83-1 & Sigma & 99.5 \\
\hline 2-Methyl-1-butanol & $1565-80-6$ & Fluka & 98.0 \\
\hline 3-Methyl-1-butanol & $123-51-3$ & Fluka & 98.5 \\
\hline trans-2-Hexen-1-ol & $928-95-0$ & Fluka & 95.0 \\
\hline Linalol (3,7-Dimethyl-1,6-octadien-3-ol) & $78-70-6$ & Fluka & 97.0 \\
\hline 2-Phenylethanol & $60-12-8$ & Fluka & 99.0 \\
\hline Butanoic acid & $107-62-6$ & Fluka & 99.0 \\
\hline 3-Methyl butanoic acid (isovaleric acid) & $503-74-2$ & Fluka & 98.0 \\
\hline Hexanoic acid & $142-62-1$ & Fluka & 99.5 \\
\hline Dodecanoic acid & $143-07-7$ & Fluka & 99.5 \\
\hline $\begin{array}{l}\text { 2-Methyl-1-propyl acetate (isobutyl } \\
\text { acetate) }\end{array}$ & $110-19-0$ & Fluka & 99.0 \\
\hline Ethyl butyrate & $105-54-4$ & Merck & 98.0 \\
\hline $\begin{array}{l}\text { 3-Methyl-1-buthyl acetate (isoamyl } \\
\text { acetate) }\end{array}$ & $123.92-2$ & Aldrich & 95.0 \\
\hline Ethyl hexanoate & $123-66-0$ & Fluka & 99.0 \\
\hline Ethyl octanoate & $106-32-1$ & Merck & 98.0 \\
\hline $\begin{array}{l}\text { DL-Malic acid diethyl ester (diethyl } \\
\text { malate) }\end{array}$ & $626-11-9$ & TCI & 98.0 \\
\hline Acetic acid & $64-19-7$ & $\begin{array}{l}\text { Riedel- } \\
\text { deHaën }\end{array}$ & 99.8 \\
\hline Furfural & $98-01-1$ & Fluka & 99.0 \\
\hline $\begin{array}{l}\text { 5-Methyl-2-furancarboxaldehyde } \\
\text { (5-methylfurfural) }\end{array}$ & $620-02-0$ & Fluka & 97.0 \\
\hline 5-Hydroxymethyl-2-furaldehyde (HMF) & $67-47-0$ & $\begin{array}{l}\text { Acros- } \\
\text { Organics }\end{array}$ & 98.0 \\
\hline (cis, trans) $\beta$-Methyl- $\gamma$-octalactone & $39212-23-2$ & Aldrich & 98.0 \\
\hline 2-Methoxyphenol (guaiacol) & 90-05-1 & Fluka & 98.0 \\
\hline 4-Methylguaiacol & $93-51-6$ & $\mathrm{TCI}$ & 95.0 \\
\hline $\begin{array}{l}\text { 2-Methoxy-4-(2-propenyl)phenol } \\
\text { (eugenol) }\end{array}$ & $97-53-0$ & Fluka & 99.0 \\
\hline 2,6-Dimethoxyphenol (syringol) & 91-10-1 & Fluka & 97.0 \\
\hline $\begin{array}{l}\text { 2,6-Dimethoxy-4-methyl-phenol } \\
\text { (4-methylsyringol) }\end{array}$ & $6638-05-7$ & Aldrich & 97.0 \\
\hline $\begin{array}{l}\text { 4-Allyl-1,2-dimethoxyphenol } \\
\text { (4-allylsyringol) }\end{array}$ & $6627-88-9$ & Aldrich & 90.0 \\
\hline $\begin{array}{l}\text { 4-Hydroxy-3-methoxy-benzaldehyde } \\
\text { (vanillin) }\end{array}$ & $121-33-5$ & Fluka & 99.0 \\
\hline $\begin{array}{l}\text { 1-(4-Hydroxy-3-methoxyphenyl) } \\
\text { ethanone (acetovanillone) }\end{array}$ & $498-02-2$ & Aldrich & 98.0 \\
\hline 4-Ethylguaiacol & $2785-89-9$ & $\mathrm{TCI}$ & 97.0 \\
\hline $\begin{array}{l}\text { 5-Methyl-2-hexanol (internal } \\
\text { standard 1) }\end{array}$ & $627-59-8$ & Fluka & 98.0 \\
\hline $\begin{array}{l}\text { 3,4-Dimethyl-phenol (internal } \\
\text { standard 2) }\end{array}$ & $95-65-8$ & Fluka & 98.0 \\
\hline $\begin{array}{l}\text { 5-Methyl-2-pentanol (internal } \\
\text { standard for higher alcohols) }\end{array}$ & $108-11-2$ & Aldrich & 98.0 \\
\hline
\end{tabular}

capillary column of polyethylene glycol (INNOWax of J\&W Scientific, Folsom, CA, USA), $30 \mathrm{~m}, 0.32 \mathrm{~mm}$ i.d., $0.25 \mu \mathrm{m}$ film thickness. The injection volume was $0.8 \mu \mathrm{L}$ for wood volatile extracts. Operating conditions were as follows: injector and detector $\left(250{ }^{\circ} \mathrm{C}\right)$; carrier gas hydrogen $\left(2.4 \mathrm{~mL} \mathrm{~min}^{-1}\right.$. and split ratio $\left.1: 25\right)$; oven temperature program: $3.5^{\circ} \mathrm{C} \mathrm{min}^{-1}$ from $35^{\circ} \mathrm{C}$ ( 6 min isothermal) until $55^{\circ} \mathrm{C}, 7.5^{\circ} \mathrm{C} \min ^{-1}$ until $130{ }^{\circ} \mathrm{C}, 5^{\circ} \mathrm{C} \min ^{-1}$ until $210^{\circ} \mathrm{C}$ and held at this temperature for $30 \mathrm{~min}$.

The quantification was done by extraction and analysis of hydroalcoholic solution of standard compounds under the same conditions and the results were expressed as $\mu \mathrm{g} / \mathrm{g}$ of dry wood.

\subsubsection{Identification of volatile compounds by GC-MS}

GC-MS analysis was performed using an Agilent 7890A gas chromatograph equipped with a DB-WAX capillary column ( $30 \mathrm{~m} \times 0.25 \mathrm{~mm} \times 0.25 \mu \mathrm{m}$; J\&W, Folsom, CA), coupled to an Agilent 5973 mass selective detector (Agilent, CA, USA). The oven program was similar to that described previously for GC-FID and the volume injected was $0.8 \mu \mathrm{L}$. The injector temperature was maintained at $250{ }^{\circ} \mathrm{C}$, the transfer line temperature was $260{ }^{\circ} \mathrm{C}$ and the flow rate of carrier gas (helium) was $0.7 \mathrm{~mL} \mathrm{~min}^{-1}$. Mass spec- tra were obtained in the electron impact (EI) mode (ionisation energy, $70 \mathrm{eV}$; source temperature, $230^{\circ} \mathrm{C}$ ). The acquisition was in full-scan mode (mass range $m / z 20-450$ ) under autotune conditions. The identification was done by comparing their mass with the NIST library and by comparing the mass spectra and retention time with standards.

\subsection{Brandy analysis}

\subsubsection{Analysis of major volatile compounds by GC-FID}

Major volatiles compounds included two odorant compounds, namely 2-methyl-1-propanol and 2+3-methyl-1-butanol. They were analysed by direct injection of brandy distillate on the chromatograph Focus GC (Thermo Scientific, USA) using the methodology previously validated (Luís, Mota, Anjos, \& Caldeira, 2011). The chromatograph Focus GC was equipped with a flame ionization detector (FID) and a fused silica capillary column of polyethylene glycol (DB-WAX of J\&W Scientific, Folsom, CA, USA), $60 \mathrm{~m}$, $0.32 \mathrm{~mm}$ i.d., $0.25 \mu \mathrm{m}$ film thickness. The operating conditions were as follows: injector $\left(200^{\circ} \mathrm{C}\right)$ detector $\left(250^{\circ} \mathrm{C}\right)$; carrier gas hydrogen (3.4 $\mathrm{mL} \mathrm{min}^{-1}$ and split ratio 1:6); oven temperature program: $10{ }^{\circ} \mathrm{C} \mathrm{min}^{-1}$ from $35^{\circ} \mathrm{C}\left(8 \mathrm{~min}\right.$ isothermal) to $200{ }^{\circ} \mathrm{C}$ and kept at this temperature for $9 \mathrm{~min}$. The injection volume was $1 \mu \mathrm{L}$ for brandy distillates.

The quantification was done through the analysis under the same conditions, of hydroalcoholic standard solutions containing known amounts of the volatile compounds.

\subsubsection{Analysis of minor volatile compounds by GC-FID}

The most odorant compounds of brandies are minor volatiles. Prior to the analysis by GC-FID and GC-MS, these odorant compounds should be extracted from the brandies and concentrated.

As such, volatile compounds were extracted from $100 \mathrm{~mL}$ of brandy samples (previously diluted to $20 \% \mathrm{v} / \mathrm{v}$ ) using discontinuous ultrasound liquid-liquid extraction with redistilled dichloromethane dried over sodium sulphate anhydrous and then concentrated to a final volume of $100-200 \mu \mathrm{L}$ (Caldeira et al., 2004). The brandy extraction was performed in duplicate and the extracts were stored at $-20^{\circ} \mathrm{C}$ until GC-FID and GC-MS analysis.

The gas chromatographic analysis was carried out in Agilent Technologies 6890 Series chromatograph (Wilmington, DE, USA) equipped with a flame ionization detector (FID) and a fused silica capillary column of polyethylene glycol (INNOWax of J\&W Scientific, Folsom, CA, USA), $30 \mathrm{~m}, 0.32 \mathrm{~mm}$ i.d., $0.25 \mu \mathrm{m}$ film thickness. The injection volume was $0.8 \mu \mathrm{L}$ and the operating conditions were as follows: injector and detector $\left(250^{\circ} \mathrm{C}\right)$; carrier gas hydrogen (2.4 $\mathrm{mL} \mathrm{min}^{-1}$. and split ratio $\left.1: 25\right)$; oven temperature program: $3.5^{\circ} \mathrm{C} \mathrm{min}^{-1}$ from $35^{\circ} \mathrm{C}$ (6 min isothermal) to $55^{\circ} \mathrm{C}, 7.5^{\circ} \mathrm{C} \mathrm{min}^{-1}$ to $130{ }^{\circ} \mathrm{C}, 5^{\circ} \mathrm{C} \mathrm{min}^{-1}$ to $210^{\circ} \mathrm{C}$ and kept at this temperature for $30 \mathrm{~min}$.

Standard solutions (hydroalcoholic solution 55\% v/v, pH 4.2) containing known amounts of the volatile compounds (previously diluted to $20 \% \mathrm{v} / \mathrm{v}$ ) were extracted and analysed using the same procedure. The results were used for the construction of calibration curves and to perform the odorant quantification.

\subsubsection{Analysis of volatile compounds by GC-MS}

The analysis was performed in a GC-MS (Magnum, Finnigan Mat, San Jose, CA, USA). The GC was equipped with a fused silica capillary column of polyethylene glycol (INNOWAX of J \& W Scientific, Folsom, CA, USA), $30 \mathrm{~m}, 0.25 \mathrm{~mm}$ i.d., $0.25 \mu \mathrm{m}$ film thickness. Operating conditions were as follows: injector and interface temperature, $250^{\circ} \mathrm{C}$; carrier gas helium (inlet pressure $83 \mathrm{KPa}$ and split ratio 1:60); oven temperature program: $3.5^{\circ} \mathrm{C} \mathrm{min}^{-1}$ from $35^{\circ} \mathrm{C}$ (6 min isothermal) to $55^{\circ} \mathrm{C}, 7.5^{\circ} \mathrm{C} \min ^{-1}$ to $130{ }^{\circ} \mathrm{C}, 5^{\circ} \mathrm{C} \mathrm{min}{ }^{-1}$ to 
$210^{\circ} \mathrm{C}$ and kept at this temperature for $30 \mathrm{~min}$; volume injected $0.4 \mu \mathrm{L}$.

The mass spectrometer was operated in the electron impact mode at $70 \mathrm{eV}$, scanning the range $\mathrm{m} / \mathrm{z} 40-340$. Identification of volatile compounds was achieved by the comparison of the GC retention times and mass spectra with those of pure standard compounds. All mass spectra were also compared with those of the data system library (NIST and WILEY).

\subsection{Statistical analysis}

Analysis of variance (ANOVA) - The results of odorant quantification on the aged brandy samples were submitted to a two-way analysis of variance, with ageing system (2 levels: B and S) and ageing time ( 7 levels: 8, 15, 90, 189, 365, 545, 735 days) as fixed factors. Calculation of the least significant difference (LSD) was applied, for comparison of the different averages, of the volatile compounds. This test was also applied to compare the results of odorant in the brandies from the two ageing systems with those of the control sample after two years of ageing.

For the wood analysis results, a one-way ANOVA was performed to compare the volatile composition of toasted woods from staves (WS) and from the barrels (WB).

All the calculations were performed using Statgraphicsstatistical system, vs 7.0.

Multivariate analysis - The brandy results were also subjected to the multivariate analysis, namely principal component analysis. All the calculations were performed using NTSYS-pc package, version $2.1 \mathrm{q}$.

\section{Results and discussion}

This study evaluated the odorant compounds assigned in the brandy chromatograms (Supplementary material). Some of these compounds derived from the distillate, namely esters, acids and alcohols, while others originated from the wood, during the ageing process such as furanic aldehydes, phenolic aldeydes, lactones and volatile phenols. The 4-ethylguaiacol is also present but at a residual level, thus it was not quantified in the brandy samples. Regarding the odorant compounds proceeding from the wood, they were also quantified in the toasted wood used in each system. The results of volatile quantification in woods and brandies are summarised in Table 2 . All of these compounds were previously identified as key-odorant compounds in aged brandies and the odorant descriptors are also presented along with the odour thresholds.

\subsection{Odorant compounds from the distillate - alcohols, esters, terpenes and acids}

The initial distillate without ageing, the control sample (C), had as expected, several odorant compounds, namely alcohols, acids and esters (Table 2), because these compounds usually proceed from grapes and yeast metabolism (Nykänen \& Suomalainen, 1983).

Most of these compounds are significantly affected by the ageing time and only four compounds (2+3 methyl-1-butanol, dodecanoic acid, isobutyl acetate and diethyl malate) are also affected by the ageing system.

The amount of the majority of these compounds vary over time (Fig. 1) but after two years of ageing a decrease was verified for most of them. Only the trans-2-hexenol content decreases continuously over the ageing period (Fig. 1B). With regards to the esters, an increase of ethyl octanoate and diethyl malate was detected over time (Fig. 1D). A similar pattern was reported in Cognac by Puech et al. (1984) for some of these compounds.
The variation amounts, over time, of the majority of these compounds could be explained by its participation in several reactions that take place during the ageing process and that could promote either the increase or the decrease of these compounds. The evaporation studied in whiskies over a year promoted a decrease of several alcohols and esters (Yoshizawa, Momose, \& Hasuo, 1981). The evaporation that results in the decrease of ethanol strength and loss of volume of the brandies could result in a concentration effect as reported by Puech et al. (1984). Other reactions like the oxidation of some acids with the formation of ketones (Watts \& Butzke, 2003), alcohols oxidation (Reazin et al., 1976) acetalization (Puech et al., 1984) and the acid catalysed esterification and hydrolysis of the esters (Nykänen \& Suomalainen, 1983) are also reported.

With the ageing system it was verified that the 2+3-methyl-1butanol, isobutyl acetate and diethyl malate amounts are higher in brandies aged in barrels in comparison with those aged in stainless steel with staves while the dodecanoic acid is higher in brandies aged in stainless steel with staves in comparison with those aged in barrels (Table 2). Caldeira et al. (2010) found similar result for isobutyl acetate in a pilot scale ageing experiment.

\subsection{Odorant compounds derived from the wood}

The odorant compounds, derived from the wood, are volatile phenols, vanillin, $\beta$-methyl- $\gamma$-octalactone, furanic aldehydes and acetic acid. The significance of these compounds to the aroma of aged wine brandies is recognized from olfactometric data and from the important correlations with sensory attributes of the brandies (Caldeira et al., 2008). They present odorant notes like toasted, smoke, vanilla, dried fruits, coconut and sweet (Table 2) which are positively correlated with the overall quality of the brandies (Caldeira et al., 2006). Furthermore, the brandy amounts of the majority of these compounds are higher than the corresponding odour threshold which explains their sensory importance.

\subsubsection{Furanic aldehydes and acetic acid}

The acetic acid proceed from the distillate, from the oxidation of ethanol via acetaldehyde and also from the oak wood, like the radioactive assay conducted by Reazin et al. (1976) has been demonstrated. The acetic acid proceeds from the acetyl groups present in the wood xylans, an important group of wood hemicelluloses (Fengel \& Wegener, 1989). The acetic acid is already present in the control brandy, but its content increased significantly over time in the two ageing systems (Table 2). The acetic acid enhancement during the wood ageing is more marked in brandies aged in wooden barrels (Fig. 2A). However, in spite of a similar heating process at the cooperage the wood composition is significant different in staves in comparison with wood of barrels (Table 2). These differences could be justified with the results of other researchers who have shown that the different wood shapes and the different heating processes results in very different wood composition (Campbell, Sykes, Sefton, \& Pollnitz, 2005; Chatonnet, 2008). The staves presented high levels of acetic acid than the wood from the barrels, but on the contrary the brandies aged in barrels presented the highest level of acetic acid, which could explain higher levels of related ester, the isobutyl acetate above mentioned.

The furanic aldehydes (furfural, 5-methylfurfural and 5hydroxymethylfurfural) are mainly originated from the degradation of wood polysaccharides, hemicelluloses and cellulose (Fengel \& Wegener, 1989). However, furfural and 5methylfurfural are also present at low levels in the control sample (Table 2), as a result of thermal reactions of the wine sugars during the distillation. 
Table 2

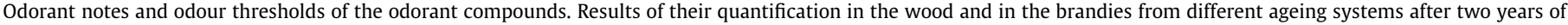
ageing, and in brandy control (without ageing). Summary of one way and two-way ANOVA are presented.

\begin{tabular}{|c|c|c|c|c|c|c|c|c|c|c|}
\hline \multirow[t]{2}{*}{$\begin{array}{l}\text { Odorant compounds (peak } \\
\text { number at supplementary } \\
\text { material) }\end{array}$} & \multirow[t]{2}{*}{$\begin{array}{l}\text { Odour } \\
\text { descriptor }\end{array}$} & \multirow[t]{2}{*}{$\begin{array}{l}\text { Odour detection } \\
\text { threshold } \\
\left(\mathrm{mg} \mathrm{dm}^{-3}\right)\end{array}$} & \multicolumn{2}{|c|}{$\begin{array}{l}\text { Odorant compounds } \\
\text { in woods ( } \mu \mathrm{g} / \mathrm{g} \text { of dry } \\
\text { wood) }\end{array}$} & \multicolumn{3}{|c|}{$\begin{array}{l}\text { Odorant compounds in } \\
\text { brandies }\left(\mathrm{mg} \mathrm{dm}^{-3}\right)\end{array}$} & \multicolumn{3}{|c|}{ ANOVA summary of brandy results } \\
\hline & & & $\begin{array}{l}\text { Barrels } \\
(\mathrm{WB})\end{array}$ & $\begin{array}{l}\text { Staves } \\
\text { (WS) }\end{array}$ & $\begin{array}{l}\text { Control } \\
\text { (C) }\end{array}$ & $\begin{array}{l}\text { Barrels } \\
\text { (B) }\end{array}$ & $\begin{array}{l}\text { Staves } \\
(\mathrm{S})\end{array}$ & $\begin{array}{l}\text { Ageing } \\
\text { system } \\
\text { (factor1) }\end{array}$ & $\begin{array}{l}\text { Ageing } \\
\text { time } \\
\text { (factor2) }\end{array}$ & $\begin{array}{l}\text { Factor } \\
\text { interaction }\end{array}$ \\
\hline Isobutanol (3) & $\begin{array}{l}\text { Smoke, } \\
\text { herbaceous }^{\xi}\end{array}$ & $40 ; 75^{\rho}$ & - & - & $710.0^{\mathrm{b}}$ & $638.0^{\mathrm{a}}$ & $632.0^{\mathrm{a}}$ & ns & 0.003 & - \\
\hline 2+3-Methyl-1-butanol (5) & $\begin{array}{l}\text { Stinky, } \\
\text { unpleasant }\end{array}$ & $7 ; 30^{\rho}$ & - & - & $1365.5^{\mathrm{b}}$ & $1264.8^{\mathrm{a}}$ & $1249.3^{\mathrm{a}}$ & 0.041 & 0.000 & ns \\
\hline trans-2-Hexen-1-ol (7) & $\begin{array}{l}\text { Cabbage, } \\
\text { flowery }^{\xi}\end{array}$ & $0.020 ; 0,5^{\rho}$ & - & - & $0.58^{\mathrm{a}}$ & $0.55^{\mathrm{a}}$ & $0.55^{\mathrm{a}}$ & ns & 0.000 & - \\
\hline Linalol (11) & $\begin{array}{l}\text { Flowery, } \\
\text { violets }^{\xi}\end{array}$ & $0.025^{\pi}$ & - & - & $0.50^{\mathrm{a}}$ & $0.45^{\mathrm{a}}$ & $0.40^{\mathrm{a}}$ & ns & 0.000 & - \\
\hline 2-Phenylethanol (18) & Roses, flowery ${ }^{\xi}$ & $7.5 ; 10^{\rho}$ & - & - & $15.04^{\mathrm{a}}$ & $13.90^{\mathrm{a}}$ & $13.48^{\mathrm{a}}$ & ns & 0.000 & - \\
\hline Butanoic acid (13) & Butter, cheese $e^{\xi}$ & $4 ; 10^{\rho}$ & - & - & $0.46^{\mathrm{a}}$ & $0.58^{\mathrm{a}}$ & $0.56^{\mathrm{a}}$ & ns & 0.009 & - \\
\hline Isovaleric acid (14) & Stinky, cheese $e^{\xi}$ & $0.033^{\pi}$ & - & - & $1.03^{\mathrm{b}}$ & $0.87^{\mathrm{a}, \mathrm{b}}$ & $0.80^{\mathrm{a}}$ & ns & 0.000 & - \\
\hline Hexanoic acid (15) & $\begin{array}{l}\text { Smoke, flowery, } \\
\text { pharmacy }^{\xi}\end{array}$ & $3 ; 8^{\rho}$ & - & - & $1.65^{\mathrm{b}}$ & $1.52^{\mathrm{a}, \mathrm{b}}$ & $1.34^{\mathrm{a}}$ & ns & 0.000 & - \\
\hline Dodecanoic acid(26) & Soap ${ }^{\xi}$ & $7.2^{\theta}$ & - & - & $0.71^{\mathrm{a}}$ & $0.49^{\mathrm{a}}$ & $0.58^{\mathrm{a}}$ & 0.000 & 0.024 & ns \\
\hline Isobutyl acetate (1) & Sweet, solvent ${ }^{\theta}$ & $3.4^{\theta}$ & - & - & $1.06^{\mathrm{a}}$ & $0.96^{\mathrm{a}}$ & $0.78^{\mathrm{a}}$ & 0.009 & 0.000 & ns \\
\hline Ethyl butyrate (2) & Fruity $^{\xi}$ & $0.02^{\rho}$ & - & - & $0.60^{\mathrm{a}}$ & $0.61^{\mathrm{a}}$ & $0.55^{\mathrm{a}}$ & ns & ns & - \\
\hline Isoamyl acetate (4) & Fruity, banana ${ }^{\xi}$ & $0.03^{\rho}$ & - & - & $2.52^{\mathrm{a}}$ & $2.42^{\mathrm{a}}$ & $2.31^{\mathrm{a}}$ & ns & ns & - \\
\hline Ethyl hexanoate (6) & Fruity, floral ${ }^{\xi}$ & $0.005^{\rho}$ & - & - & $1.11^{\mathrm{a}}$ & $1.23^{\mathrm{c}}$ & $1.19^{\mathrm{b}}$ & ns & ns & - \\
\hline Ethyl octanoate (8) & Flowery, fruity ${ }^{\xi}$ & $0.002 ; 0.26^{\rho}$ & - & - & $1.94^{\mathrm{a}}$ & $2.25^{\mathrm{a}}$ & $2.21^{\mathrm{a}}$ & ns & 0.000 & - \\
\hline Diethyl malate (22) & $\begin{array}{l}\text { Sweet, sweet } \\
\text { cotton }^{\xi}\end{array}$ & - & - & - & $0.02^{\mathrm{a}}$ & $0.19^{c}$ & $0.04^{\mathrm{b}}$ & 0.000 & 0.000 & 0.000 \\
\hline Acetic acid (9) & Vinegar $^{\xi}$ & $26^{\theta}$ & $5596.70^{\mathrm{a}}$ & $16051.30^{\mathrm{a}}$ & $111.7^{\mathrm{a}}$ & $440.9^{c}$ & $164.1^{\mathrm{b}}$ & 0.000 & 0.000 & 0.000 \\
\hline Furfural (10) & $\begin{array}{l}\text { Fresh bread } \\
\text { smoky, almond }^{\rho}\end{array}$ & $5.8^{\theta}$ & $556.59^{\mathrm{a}}$ & $2975.56^{\mathrm{b}}$ & $10.38^{\mathrm{a}}$ & $44.32^{\mathrm{b}}$ & $40.18^{\mathrm{b}}$ & 0.017 & 0.000 & ns \\
\hline 5-Methylfurfural (12) & $\begin{array}{l}\text { Dry, fried, } \\
\text { tobacco } \psi\end{array}$ & $16^{\theta}$ & $66.15^{\mathrm{a}}$ & $214.50^{\mathrm{b}}$ & $0.45^{\mathrm{a}}$ & $3.84^{c}$ & $2.27^{\mathrm{b}}$ & 0.000 & 0.000 & ns \\
\hline $\operatorname{HMF}(27)$ & Caramel, fried ${ }^{\psi}$ & - & $204.87^{\mathrm{a}}$ & $172.73^{\mathrm{a}}$ & $0.00^{\mathrm{a}}$ & $16.29^{\mathrm{b}}$ & $2.91^{\mathrm{a}}$ & 0.000 & 0.000 & 0.000 \\
\hline $\begin{array}{l}\text { trans- } \beta \text {-Methyl- } \gamma \text {-octalactone } \\
\quad \text { (17) }\end{array}$ & Sweet, flowery ${ }^{\xi}$ & $0.79^{\theta}$ & $5.32^{\mathrm{a}}$ & $2.55^{\mathrm{a}}$ & $0.00^{\mathrm{a}}$ & $0.17^{\mathrm{b}}$ & $0.04^{\mathrm{a}}$ & 0.000 & 0.000 & 0.018 \\
\hline $\begin{array}{l}\text { cis- } \beta \text {-Methyl- } \gamma \text {-octalactone } \\
\quad(19)\end{array}$ & Coconut, sweet ${ }^{\xi}$ & $0.067^{\theta}$ & $21.47^{\mathrm{a}}$ & $20.47^{\mathrm{a}}$ & $0.00^{\mathrm{a}}$ & $0.69^{c}$ & $0.13^{\mathrm{b}}$ & 0.000 & 0.000 & 0.000 \\
\hline Guaiacol (16) & $\begin{array}{l}\text { Smoky, } \\
\text { medicinal-like }\end{array}$ & $0.0092^{\varpi}$ & $2.63^{\mathrm{a}}$ & $11.21^{\mathrm{b}}$ & $0.00^{\mathrm{a}}$ & $0.11^{\mathrm{a}, \mathrm{b}}$ & $0.17^{\mathrm{b}}$ & 0.000 & 0.000 & 0.001 \\
\hline 4-Methyl-guaiacol (20) & $\begin{array}{l}\text { Smoky, burned } \\
\text { wood }^{\rho}\end{array}$ & $0.23^{\sigma}$ & $3.77^{\mathrm{a}}$ & $12.32^{\mathrm{b}}$ & $0.00^{\mathrm{a}}$ & $0.15^{b}$ & $0.13^{\mathrm{b}}$ & 0.000 & 0.000 & 0.001 \\
\hline Eugenol (23) & Flowery, clove $\xi$ & $0.0070^{\sigma}$ & $5.70^{\mathrm{b}}$ & $4.46^{\mathrm{a}}$ & $0.00^{\mathrm{a}}$ & $0.38^{\mathrm{c}}$ & $0.15^{\mathrm{b}}$ & 0.000 & 0.000 & 0.000 \\
\hline Syringol (24) & $\begin{array}{l}\text { Burnt, smoke, } \\
\text { burned wood }\end{array}$ & $0.58^{\sigma}$ & $9.26^{\mathrm{a}}$ & $41.78^{\mathrm{b}}$ & $0.00^{\mathrm{a}}$ & $0.17^{\mathrm{b}}$ & $0.54^{\mathrm{c}}$ & 0.000 & 0.000 & 0.000 \\
\hline 4-Methylsyringol (25) & $\begin{array}{l}\text { Smoke, burned, } \\
\text { flowery }\end{array}$ & - & $8.08^{\mathrm{a}}$ & $30.71^{\mathrm{b}}$ & $0.00^{\mathrm{a}}$ & $0.24^{\mathrm{b}}$ & $0.53^{\mathrm{c}}$ & 0.000 & 0.000 & 0.000 \\
\hline 4-Allylsyringol (28) & $\begin{array}{l}\text { Flowery, } \\
\text { carnation, } \\
\text { smoke burned }\end{array}$ & $3^{\theta}$ & $8.27^{\mathrm{a}}$ & $16.34^{\mathrm{b}}$ & $0.00^{\mathrm{a}}$ & $0.33^{b}$ & $0.35^{\mathrm{b}}$ & ns & 0.000 & - \\
\hline Vanillin (29) & Vanilla & $0.022^{\varpi}$ & $99.97^{\mathrm{a}}$ & $158.66^{\mathrm{b}}$ & $0.00^{\mathrm{a}}$ & $4.28^{\mathrm{c}}$ & $3.44^{\mathrm{b}}$ & 0.001 & 0.000 & ns \\
\hline Acetovanillone (30) & Vanilla $^{\theta}$ & $15^{\theta}$ & $1.39^{\mathrm{a}}$ & $8.09^{\mathrm{b}}$ & $0.00^{\mathrm{a}}$ & $0.42^{\mathrm{b}}$ & $0.56^{\mathrm{c}}$ & 0.000 & 0.000 & 0.000 \\
\hline
\end{tabular}

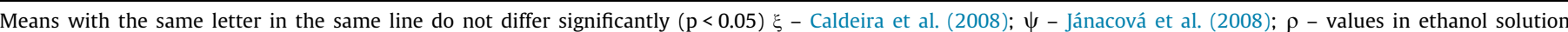

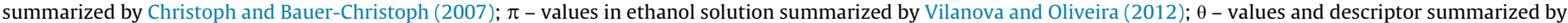
Caldeira (2004); $\boldsymbol{\varpi}$ - values established in ethanol solution by Willner, Granvogl, and Schieberle (2013).

As for acetic acid, a significant effect of the ageing system and the ageing time on the amounts of the three furanic aldehydes was detected. All of them are present at higher amounts in brandies aged in wooden barrels than in brandies aged in stainless steel tanks with staves, in accordance with previous results obtained in pilot scale ageing experiment (Caldeira et al., 2010; Canas et al., 2013). Conversely higher amounts of furfural and 5methylfurfural were detected in toasted wood from staves (Table 2). These results led us to hypothesize the occurrence of other reactions involving furanic aldehydes and/or their precursors in the brandies aged in stainless steel with staves.

The increment of acetic acid and furanic aldehydes follow a hyperbolic pattern with the greatest increase in the first 90 days. The rise is always higher in the brandies aged in wooden barrels. After that the amount of compounds seems to reach the equilib- rium (Fig. 2A and B). Similar patterns have been found in model wine and wine brandies (Canas et al., 2013; Puech et al., 1984; Spillman, Iland, \& Sefton, 1998).

\subsubsection{Volatile phenols}

The volatile phenols, guaiacol, eugenol, syringol, 4methylsyringol, 4-allylsyringol are known as odour active compounds in the aged brandies. Some of them are positively correlated with sensory attributes such as smoke, woody, spicy and toasted (Caldeira et al., 2008).

For most of the studied volatile phenols a significant influence of the ageing system, ageing time and interaction of the two factors was detected, which reflects a different evolution pattern over time in the two ageing systems. However, the amount of 4-allylsyringol in brandies is only influenced by the ageing time (Table 2). 

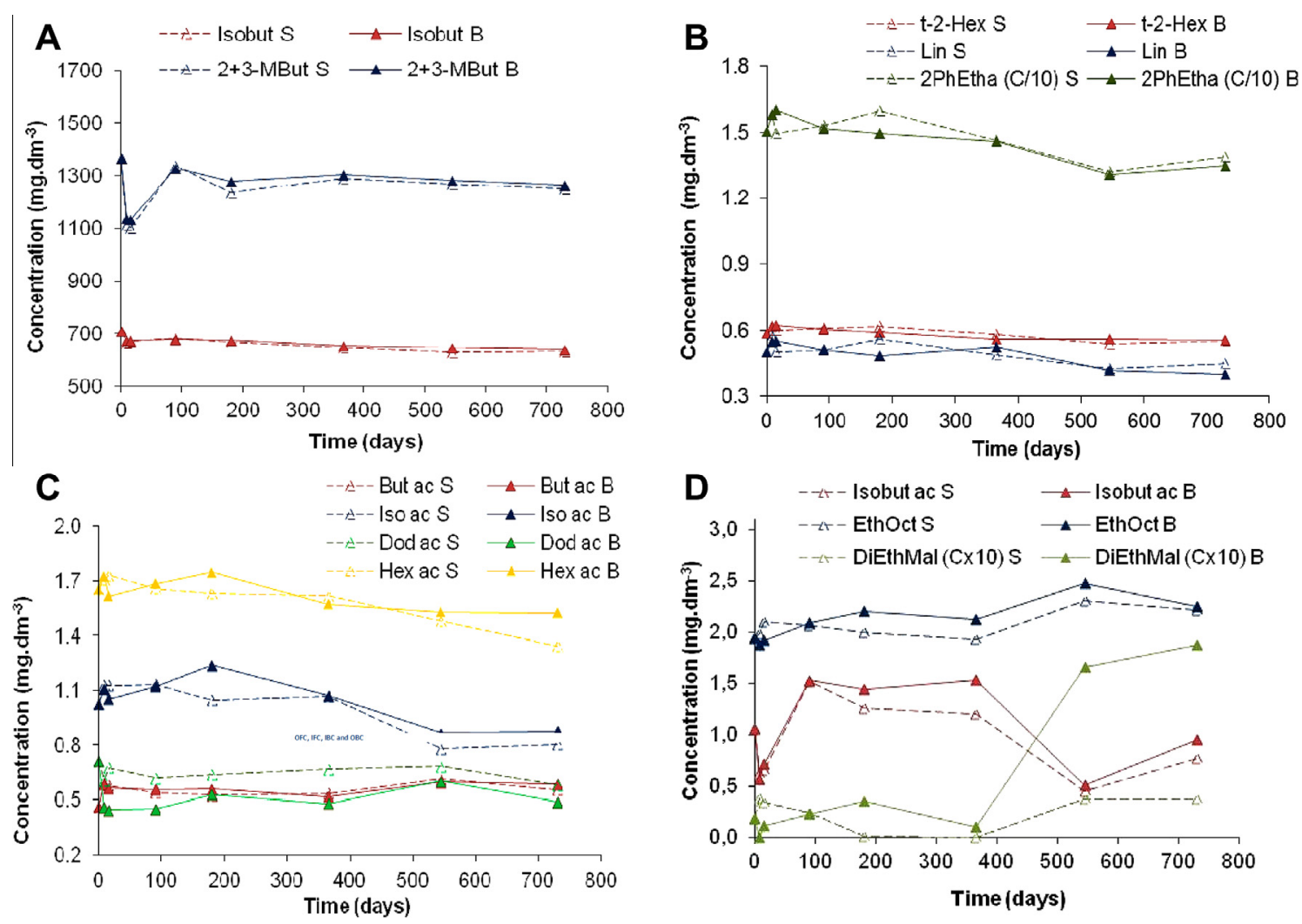

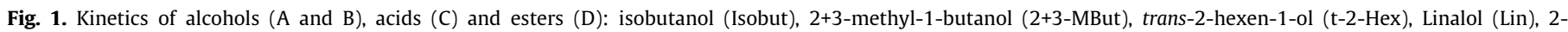

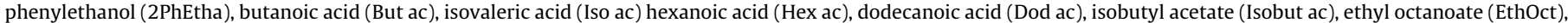

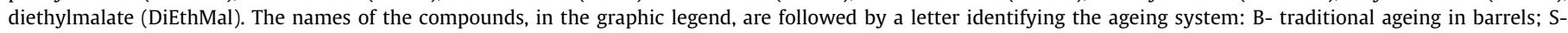
alternative ageing with staves inside the stainless steel tanks. C/10 or Cx10- concentration divided or multiplied by 10 .

In relation to the ageing system, the average amounts of 4methylsyringol and syringol are significantly higher in brandies aged in stainless steel tanks than in those aged in wooden barrels. Contrastingly, the brandies aged in wooden barrels present the highest amounts of eugenol. These data seem related to the wood volatile phenols amounts that are higher in woods from the staves than in wood from the barrels, except for eugenol that present the highest values in barrelś wood (Table 2). These results are in accordance with the previous ones obtained after an ageing time of 6 months in a pilot scale ageing experiment (Caldeira et al., 2010).

Concerning the kinetics, different results are obtained (Fig. 2C, D and E). The guaiacol content enhances over the time (Fig. 2C) with a major increment until 90 days. After this period the values tends to stabilise, although a slight increase between 545 to 730 days in wooden barrels.

The 4-methylguaiacol concentrations also increase over time (Fig. 2E), and the higher concentration is reached within the initial 90 days of ageing. After that, the equilibrium is achieved in brandies aged in stainless steel tanks with staves. While for brandies aged in wooden barrels another increase was observed and after two years of ageing the 4-methylguaiacol amounts are similar in the two ageing systems (Table 2). Spillman et al., 1998 found a quite different evolution pattern of 4-methylguaiacol and guaiacol in a model wine (hydroalcoohic solution $10 \% \mathrm{v} / \mathrm{v}$ ) stored in oak barrels.

The syringol amount increases over time (Fig. 2D), with the greatest increase up to 90 days in wooden barrels and up to 180 days in stainless steel tanks with staves, followed by stabilisation in the brandies from both systems.

The 4-methylsyringol content of the brandies also increases during the ageing period. The major increment arises in the first
15 days in wooden barrels, while in the stainless steel tanks with staves the enhancement occurs up to the 180 days of ageing. After this period the equilibrium is reached (Fig. 2D). The 4-allylsyringol also follows a hyperbolic pattern similar in the two ageing systems, which raises the maximum after 180 days of ageing and then the steady-state seems to be attained (Fig. 2C).

Regarding the eugenol content the effect of the ageing system, ageing time and interaction of both was verified. Its content is higher in brandies from wooden barrels (Table 2) and the enhancement takes place up to 545 days of ageing, while in brandies from stainless steel tanks with staves the initial amounts are lower and also increase until 545 days followed by a downward trend (Fig. 2E). The accumulation of eugenol in a model wine (hydroalcoohic solution $10 \% \mathrm{v} / \mathrm{v}$ ) stored in oak barrels pursued a similar behaviour in wooden barrels (Spillman et al., 1998).

\subsubsection{Vanillin and acetovanillone}

The presence of vanillin in aged brandies is initially reported by several authors as one of the most potent odorant of wooden aged brandies and it has been found an important correlation with vanilla sensory attribute (Caldeira et al., 2008). The acetovanillone, which presents a faint vanilla-like odour, and vanillin are both wood lignin's derived compounds (Nishimura et al., 1983).

Brandy vanillin and acetovanillonne contents are both significantly influenced by the ageing system and by the ageing time. Higher amounts of vanillin and lower amounts of acetovanillone are quantified in brandies proceeding from wooden barrels than in brandies produced in stainless steel tanks with staves. As for the acetovanillone these results reflect the wood composition, while for vanillin the brandy composition is inversely related to the wood composition (Table 2). The accumulation profile for 

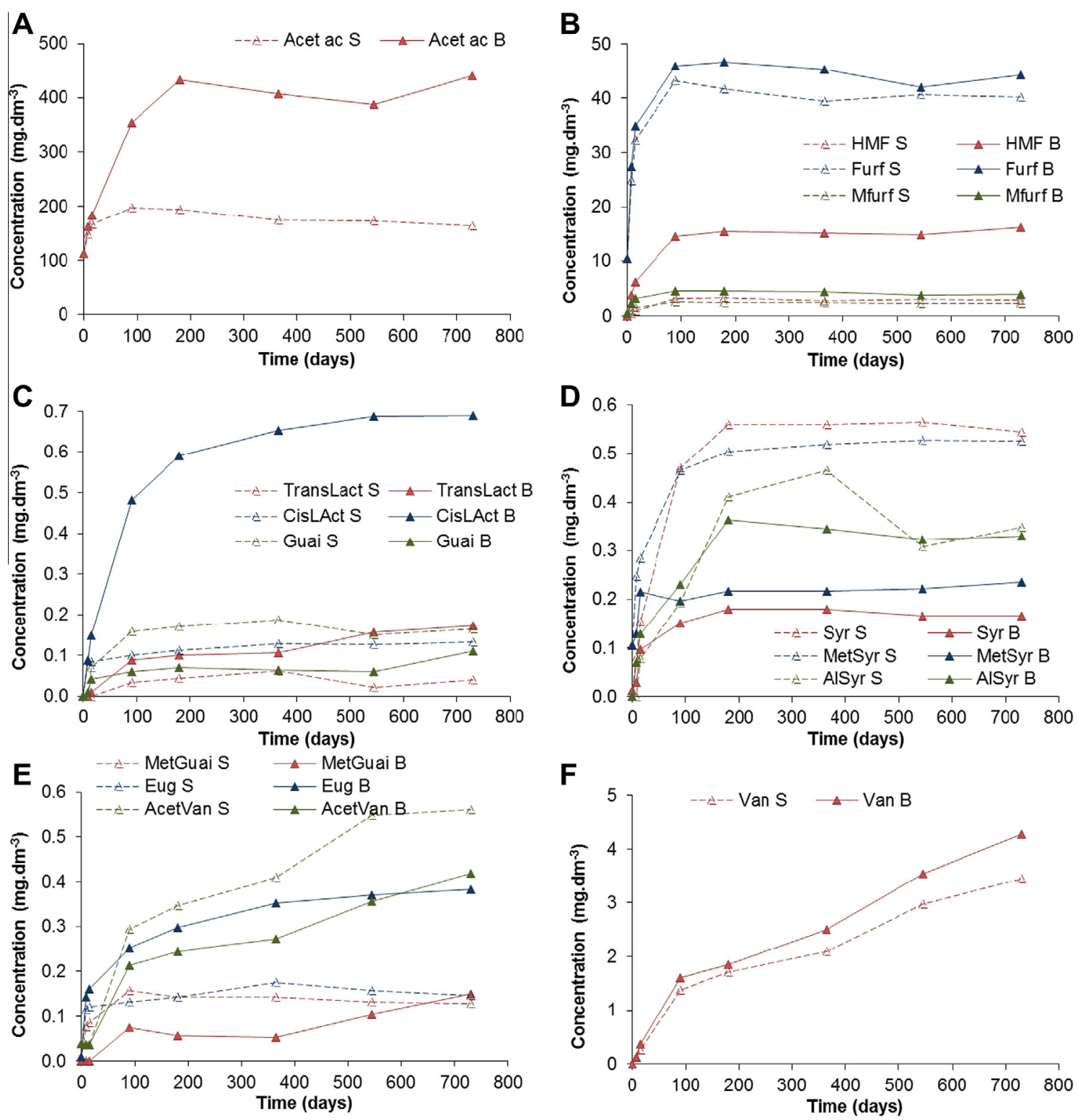

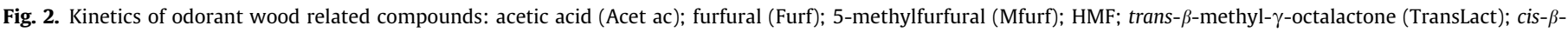

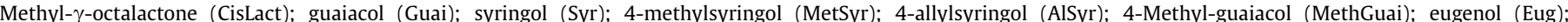

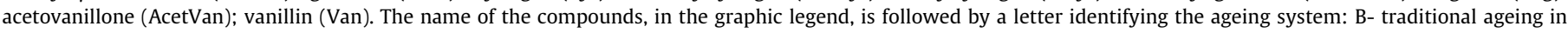
barrels; S-alternative ageing with staves inside the stainless steel tanks.

vanillin (Fig. 2F) indicates that the concentration increased asymptotically during the first 180 days. Thereafter it rises in a linear manner, with an upper slope in the barrels.

The accumulation profile of acetovanillone in the barrels is similar but the slope of linear branch is higher in the stainless steel tanks. In this case, the linear increase seems to occur from 90 to 545 days and then stabilise (Fig. 2E).

\subsection{4. cis,trans- $\beta$-Methyl- $\gamma$-octalactone}

According to our previous studies, these two isomers are odour active compounds for oak aged brandies but not for chestnut aged brandies presenting coconut and sweet aromas (Caldeira et al., 2008). They were identified many years ago in whiskies, wine, wine brandies and oak wood. The cis isomer is the more plentiful in all analysed brandies, like in other works (Caldeira et al., 2010). For the two isomers a significant effect of the ageing system, ageing time and interaction of both is assigned. With regards to the ageing system, the brandies with higher amounts in the two isomers are produced in wooden barrels in accordance with the wood analysis (Table 2). The content of cis isomer increases over time, following a hyperbolic pattern in wooden barrels (Fig. 2C). In stainless steel tanks the content of this isomer remains unchanged over time (Fig. 2C). The content of trans isomer tends to increase over time in the two ageing systems but with different patterns. In barrels a linear increase but with two phases was observed: in the first one there is a more pronounced slope up to the 90 days of ageing; in the second one there is a linear increase but with a very slight slope up to the 730 days. In stainless steel tanks with staves the accumulation of trans isomer in brandies follows a different pattern. The trans isomer concentration shows an increase after 15 days of ageing up to 365 days, followed by a final decrease.

To the best of our knowledge, apart from the observations about vanillin, furanic aldehydes and acetic acid reported in scientific literature, the kinetics of cis, trans- $\beta$-methyl- $\gamma$-octalactone, 
acetovanillone and volatile phenols (guaiacol, 4-methylguaiacol, eugenol, syringol, 4-methylsyringol, 4-allylsyringol) in wine brandies aged in wooden barrels have never been published.

The accumulation profiles of the majority of wood related odorant compounds follow a hyperbolic pattern with a great enhancement at the beginning of ageing period. This phase seems to be specific of each compound, varying from 18 to 180 days. These profiles are consistent with extraction and diffusion kinetics of the compounds from the wood into the brandy. After the wood impregnation by the brandies, the transfer of the compounds present in the surface of the wood quickly occur and then the diffusion kinetics depends on the concentration gradient between the wood and the brandy, being influenced by the wood structure and by the compound structure (Patrício, Canas, \& Belchior, 2005). Nevertheless, for some compounds, such as vanillin, acetovanillone, guaiacol, eugenol, 4-methylguaiacol and trans- $\beta$-methyl- $\gamma$-octalactone, after the initial hyperbolic increase, it was verified a linear augment suggesting its generation during ageing. The pathway of vanillin formation is known (Nishimura et al., 1983; Puech, 1981; Puech et al., 1984). The vanillin is available in the wood as a consequence of thermal lignin degradation during the toasting. Thus, the vanillin is present in the brandies as result of extraction, but also as a result of the degradation of the wood lignin by the alcoholic beverage as well as by afterward formation by oxidation. Concerning the other compounds further research is needed in order to understand their origin during the ageing process.

On the other hand, the alternative ageing system considerably modifies the accumulation pattern of the compounds. These differences result firstly from the influence of the toasted wood. In fact, the oven heating process induces higher amounts of several furanic and phenol derivatives on the staves wood than in the wood barrels heated over the fire. Nevertheless, the brandy composition does not correspond, for several compounds, to the pool of available compounds in wood, suggesting that other factors or other reactions contribute to the difference in the two ageing systems. Further research is needed to evaluate this aspect.

Despite the effort made to reproduce the traditional ageing process in the alternative system, the brandies resulting from the two ageing processes are quite different. Consequently, the possibility of discriminating the ageing technologies based on the overall composition of the brandies was investigated.

\subsection{Discrimination of brandies from different ageing systems based on odorant compounds}

Based on the previous results, the multivariate analysis to check whether the measured variables could help to distinguish among the brandies produced from the two ageing systems was applied. The data of brandy odorants contents were submitted to a Principal Component Analysis. Initially, all the variables were taken into account and the first two principal components only accounted for $62 \%$ of the variance (data not show). Afterwards the method was applied by using only the data of wood related compounds (Fig. 3). The first two principal components accounted for $89 \%$ of the total variance.

The plot of the brandy samples in the plane defined by the two components exhibits the separation of the brandies based on the ageing time and the ageing system. The first component splits the brandies over the ageing time. The younger brandies are located on the negative side of the component while the older brandies are on the opposite side. The second component, which accounted for $38 \%$ of total variance, splits the samples according to the ageing system. In fact, the brandies produced in the stainless steel tanks with staves are located on the positive side, linked to the high values of 4-methylsyringol, syringol, guaiacol, 4methylguaiacol and acetovanillone. The brandies from wooden

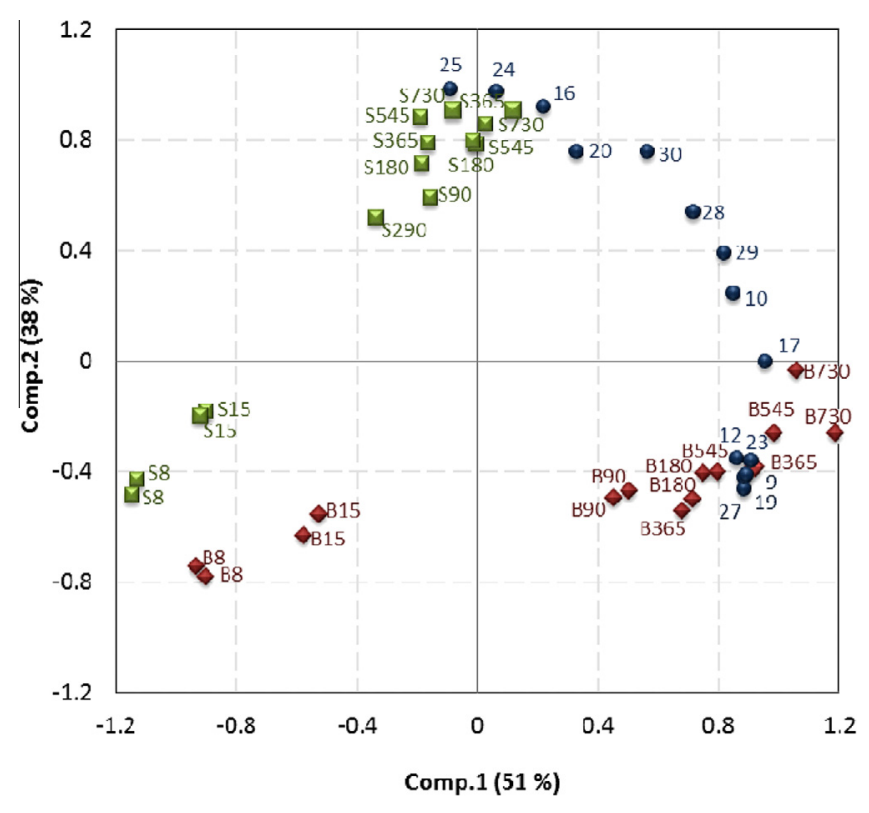

Fig. 3. Principal component analysis of data of wood odorant related compounds in brandies. Scatterplot of brandy samples on the plane defined by the two first components. Symbols: red diamonds and green squares (brandy samples) and blue circles (variables: odorant compounds). The brandy samples are identified by a first capital letter which indicate the ageing system B or S, a second number that indicate the ageing time: $8,15,90180,365,545$ or 730 . Identification of variables: 9: acetic acid, 10:furfural, 12:5-methylfurfural, 27: HMF,17: trans- $\beta$-methyl- $\gamma$ octalactone, 19: cis- $\beta$-methyl- $\gamma$-octalactone, 16:guaiacol, 20: 4-methyl-guaiacol, 23: eugenol, 24: syringol, 25: 4-methylsyringol, 28: 4-allylsyringol, 29: vanillin, 30: acetovanillone. (For interpretation of the references to colour in this figure legend, the reader is referred to the web version of this article.)

barrels are located on the negative side of component 2 closed to the high loads of 5-methylfurfural, eugenol, acetic acid, cis- $\beta$ methyl- $\gamma$-octalactone and HMF.

These results demonstrate the possibility of using the chemical composition of the brandies in order to distinguish the ageing system used. Nevertheless, a different work with a larger number of samples will be necessary to validate these results. Other authors pointed out analogous results for red wines (del Alamo Sanza, Nevares-Domínguez, Cárcel-Cárcel, \& Navas Gracia, 2004; del Álamo, Nevares, Gallego, Martin, \& Merino, 2008; HernándezOrte et al., 2014).

\section{Conclusions}

Changes in the odorant compounds' amounts, in the same Lourinhã brandy aged in wooden barrels and in stainless steel tanks with staves were evaluated during an ageing period of 24 months, on an industrial scale. To the best of our knowledge, the kinetics of cis, trans- $\beta$-methyl- $\gamma$-octalactone, acetovanillone and volatile phenols (guaiacol, 4-methylguaiacol, eugenol, syringol, 4methylsyringol, 4-allylsyringol) in brandies during ageing were determined for the first time.

The results demonstrated that the kinetics of odorant compounds depends both on the compound nature and on the ageing system.

With regards to the odorants compounds proceeding from the distillate, namely alcohols (isobutanol, 2+3-methyl-1-butanol, trans-2-hexen-1-ol, linalol, 2-phenylethanol) and acids (butanoic, isovaleric, hexanoic and dodecanoic acid) it was detected, for the majority of the compounds, a tendency to decrease over two years of ageing. Regarding the esters, also deriving from distillate, an inverse tendency for two esters was noticed (diethyl malate and 
ethyl octanoate) which increase over the time, while the other four esters (isobutyl acetate, ethyl butirate, isoamyl acetate and ethyl hexanoate) were not affected by the ageing time.

The kinetics of the majority of wood related odorant compounds (acetic acid, furanic aldehydes, volatile phenols, vanillin, acetovanillone and cis,trans- $\beta$-methyl- $\gamma$-octalactone) followed a hyperbolic pattern with the major increment at the beginning of the ageing period, along with the diffusion of the compounds from the wood into the brandies. However, for some of the wood related compounds, such as vanillin, acetovanillone, guaiacol, eugenol, 4methylguaiacol and trans- $\beta$-methyl- $\gamma$-octalactone, the initial hyperbolic increase is followed by a linear enrichment, suggesting their formation during ageing.

The ageing system significantly influenced the accumulation pattern of the compounds, mainly the wood related compounds. This effect seems to contain the influence of a cooperage heating process, which induced a different volatile wood composition to the staves and wood barrels. Consequently, the brandies produced in wooden barrels are associated to higher amounts of acetic acid, 5 -methylfurfural, eugenol, acetic acid, cis- $\beta$-methyl- $\gamma$-octalactone and HMF while the brandies from the stainless steel tanks with staves are linked to higher amounts of volatile phenols (4methylsyringol, syringol, guaiacol, 4-methylguaiacol) and acetovanillone.

\section{Acknowledgments}

The authors are grateful to Otília Cerveira for the technical support on volatile extraction and analysis of extracts by GC-FID and they are also very thankful to Isabele Lavado (IPCB Languages centre) for the English revision of the manuscript.

This work had the financial support of Tanoaria J. M. Gonçalves, Adega Cooperativa de Lourinhã, IPCB, INIAV-Dois Portos and IPS.

Centro de Estudos Florestais is a research unit funded by FCT (UID/AGR/00239-2013).

\section{Appendix A. Supplementary data}

Supplementary data associated with this article can be found, in the online version, at http://dx.doi.org/10.1016/j.foodchem.2016. 05.129.

\section{References}

Anjos, O., Carmona, C., Caldeira, I., \& Canas, S. (2013). Variation of extractable compounds and lignin contents in wood fragments used in the aging of wine brandies. Bioresources, 8, 4484-4496.

Caldeira, I. (2004). The aroma of wine brandies aged in wood. Cooperage technology relevance Ph.D. thesis. Instituto Superior de agronomia, Universidade Técnica de Lisboa, p. 238.

Caldeira, I., Anjos, O., Portal, V., Belchior, A. P., \& Canas, S. (2010). Sensory and chemical modifications of wine-brandy aged with chestnut and oak wood fragments in comparison to wooden barrels. Analytica Chimica Acta, 660, 43-52.

Caldeira, I., Belchior, A. P., \& Canas, S. (2013). Effect of alternative ageing systems on the wine brandy sensory profile. Ciência Técnica Vitivinícola, 28, 9-18.

Caldeira, I., Bruno de Sousa, R., Belchior, A. P., \& Clímaco, M. C. (2008). A sensory an chemical approach to the aroma of wooden aged Lourinhã wine brandy. Ciência Técnica Vitivinicola, 23, 97-110.

Caldeira, I., Mateus, A. M., \& Belchior, A. P. (2006). Flavour and odour profile modifications during the first five years of Lourinhã brandy maturation on different wooden barrels. Analytica Chimica Acta, 563, 264-273.

Caldeira, I., Pereira, R., Clímaco, M. C., Belchior, A. P., \& Bruno de Sousa, R. (2004). An improved method for extraction of aroma compounds in aged brandies and aqueous alcoholic wood extracts using ultrasound. Analytica Chimica Acta, 513, $125-134$.

Campbell, J. I., Sykes, M., Sefton, M. A., \& Pollnitz, A. P. (2005). The effects of size temperature and air contact on the outcome of heating oak fragments. Australian Journal of Grape and Wine Research, 11, 348-354.

Canas, S., Caldeira, I., \& Belchior, A. P. (2009a). Comparação de sistemas alternativos para o envelhecimento de aguardente vínica. Efeito da oxigenação e da forma da madeira. Ciência Técnica Vitivinicola, 24, 33-40.
Canas, S., Caldeira, I., \& Belchior, A. P. (2009b). Comparison of alternative systems for the ageing of wine brandy. Wood shape and wood botanical species effect. Ciência Técnica Vitivinicola, 24, 90-99.

Canas, S., Caldeira, I., \& Belchior, A. P. (2013). Extraction/oxidation kinetics of low molecular weight compounds in wine brandy produced in alternative ageing systems. Food Chemistry, 138, 2460-2467.

Canas, S., Caldeira, I., Belchior, A. P., Spranger, M. I., Clímaco, M. C., \& Bruno de Sousa, R. (2011). Chestnut wood: A sustainable alternative for the aging of wine brandies. In D. A. Medina \& A. M. Laine (Eds.), Food quality: Control, analysis and consumer concerns (pp. 181-228). New York: Nova Science Publishers Inc.

Canas, S., Leandro, M. C., Spranger, M. I., \& Belchior, A. P. (1999). Low molecular weight organic compounds of chestnut wood (Castanea sativa L.) and corresponding aged brandies. Journal of Agricultural and Food Chemistry, 47, 5023-5030.

Cantagrel, R., Mazerolles, G., Vidal, J. P., Galy, B., Boulesteix, J. M., Lablanquie, O., \& Gaschet, J. (1992). Évolution analytique et organoleptique des eaux-de-vie de Cognac au cours du vieillissement. Incidence des techniques de tonnelleries. In R. Cantagrel (Ed.). Elaboration et connaissance des spiritueux (pp. 567-572). Paris: TEC \& DOC-Lavoisier.

Chatonnet, P. (2008). Situation et evolution de l'utilization des alternatives dans le monde. partie 2/3: Influence de la degradation thermique du bois sur la composition et la qualité des produits alternatifs. Revue des OEnologues et des Techniques vitivinicoles et oenologiques, 126, 45-48.

Christoph, N., \& Bauer-Christoph, C. (2007). Flavour of spirit drinks: Raw materials, fermentation, distillation, and ageing. In R. G. Berger (Ed.). Flavours and fragrances: Chemistry, bioprocessing and sustainability (pp. 219-240). Berlin: Springer-Verlag.

Cruz, S., Canas, S., \& Belchior, A. P. (2012). Effect of ageing system and time on the quality of wine brandy aged at industrial-scale. Ciência Técnica Vitivinícola, 27, 83-93.

del Alamo Sanza, M., Nevares Domínguez, I., Cárcel Cárcel, L. M., \& Navas Gracia, L. (2004). Analysis for low molecular weight phenolic compounds in a red wine aged in oak chips. Analytica Chimica Acta, 513, 229-237.

del Álamo, M., Nevares, I., Gallego, L., Martin, C., \& Merino, S. (2008). Aging markers from bottled red wine aged with chips, staves and barrels. Analytica Chimica Acta, 621, 86-99.

Fengel, D., \& Wegener, G. (1989). Wood. Chemistry, ultrastructure, reactions.Berlin: Walter de Gruyter \& C.

Guichard, E., Fournier, N., Masson, G., \& Puech, J. L. (1995). Stereoisomers of $\beta$ methyl- $\gamma$-octalactone. I-Quantification in brandies as a function of wood origin and treatment of the barrels. American Journal of Enology and Viticulture, 46, 419-423.

Hernández-Orte, P., Franco, E., González Huerta, C., Martínez García, J., Cabellos, M., Suberviola, J., Orriols, I., et al. (2014). Criteria to discriminate between wines aged in oak barrels and macerated with oak fragments. Food Research International, 57, 234-241.

Jánacová, A., Sádecká, J., Kohajdová, Z., \& Spanik, I. (2008). The identification of aroma-active compounds in Slovak brandies using GC-sniffing, GC-MS and sensory evaluation. Chomatographia, 67, 113-121.

Luís, A., Mota, D., Anjos, O., \& Caldeira, I. (2011). Single-laboratory validation of determination of acetaldehyde, ethyl acetate, metanol and fusel alcohols in wine spirits, brandies and grape marc spirits using GC-FID. Ciência Técnica Vitivinícola, 26, 69-76.

Nishimura, K., \& Matsuyama, R. (1989). Maturation and maturation chemistry. In J. R. Piggott, R. Sharp, \& R. E. B. Duncan (Eds.), The science and technology of whiskies (pp. 235-263). Essex: Longman Scientific \& Technical.

Nishimura, K., Onishi, M., Masuda, M., Koga, K., \& Matsuyama, R. (1983). Reactions of wood components during maturation. In J. R. Piggott (Ed.), Flavour of distilled beverages: Origin and development (pp. 241-255). England: Ellis Horwood Limited.

Nykänen, L., \& Suomalainen, H. (1983). Aroma of beer, wine and distilled alcoholic beverages.Dordrecht, Holland: D. Reidel Pulbishing Company.

Onishi, M., Guymon, J. F., \& Crowell, E. A. (1977). Changes in some volatile constituents of brandy during aging. American Journal of Enology and Viticulture, $28,152-158$.

Otsuka, K.-I., Zenibayashi, Y., Itooh, M., \& Totsuka, A. (1974). Presence and significance of two diastereomers of $\beta$-methyl- $\gamma$-octalactone in aged distilled liquors. Agricultural and Biological Chemistry, 38, 485-490.

Patrício, I., Canas, S., \& Belchior, A. P. (2005). Effects of brandies agitation on the kinetics of extraction/oxidation and diffusion of wood extractable compounds in experimental model. Ciência Técnica Vitivinicola, 20, 1-15.

Puech, J.-L. (1981). Extraction and evolution of lignin products in Armagnac matured in oak. American Journal of Enology and Viticulture, 32, 111-114.

Puech, J. L., Leauté, R., Clot, G., Nomdedeu, L., \& Mondiés, H. (1984). Évolution de divers constituants volatils et phénoliques des eaux-de-vie de cognac au cours de leur vieillissement. Science des Aliments, 4, 65-80.

Puech, J. L., \& Goffinet, B. (1987). Adjustment of nonlinear models for lignin and its degradation products during the aging of Armagnac. Journal of Food Science, 52, 1280-1282.

Reazin, G. H., Baldwin, S., Scales, H. S., Washington, H. W., \& Andreasen, A. A. (1976). Determination of the congeners produced from ethanol during whisky maturation. Journal AOAC, 59, 770-776.

Schwarz, M., Carmen Rodríguez, M., Sánchez, M., Guillén, D. A., \& Barroso, C. G. (2014). Development of an accelerated aging method for Brandy. LWT - Food Science and Technology, 59, 108-114. 
Spillman, P. J., Iland, P. G., \& Sefton, M. A. (1998). Accumulation of volatile oak compounds in a model wine stored in American and Limousin oak barrels. Australian Journal of Grape and Wine Research, 4, 67-73.

Vilanova, M., \& Oliveira, J. M. (2012). Application of gas chromatography on the evaluation of grape and wine aroma in atlantic viticulture (NW Iberian Peninsula). In B. Salih (Ed.). Gas chromatography in plant science, wine technology, toxicology and some specific applications (pp. 109-146). Rijeka: InTech.
Watts, V. A., \& Butzke, C. E. (2003). Analysis of microvolatiles in brandy: relationship between methylketone concentration and Cognac age. Journal of Science of Food Agriculture, 83, 1143-1149.

Willner, B., Granvogl, M., \& Schieberle, P. (2013). Characterization of the key aroma compounds in Bartlett pear brandies by means of the sensomics concept. Journal of Agricultural and Food Chemistry, 61, 9583-9593.

Yoshizawa, K., Momose, H., \& Hasuo, T. (1981). Substances evaporated through barrel during aging of whisky. Nippon Nogeikagaku Kaishi, 55, 1063-1068. 